\title{
PREPARING THE NURSE TO RENDER A SERVICE TO THE MENTALLY RETARDED
}

\author{
Marina M. W. Faurie
}

Lecturer in Psychiatric Nursing Science, University of Pretoria

\section{OPSOMMING}

Die hoofdoelstellings van 'n diens aan die geestesvertraagde is rehabilitasie in die gemeenskap, of die bereiking van maksimale persoonlike en sosiale onafhanklikheid binne die omgewing van 'n sorg- en rehabilitasiesentrum.

Daarom moet die verpleegkundige opgelei word om in die normale (of primêre) menslike sowel as die buitengewone behoeftes van die geestesvertraagde te voorsien. Voorbereiding moet op primêre, sekondêre en tersiêre vlak geskied.

Dienslewering geskied in sorg- en rehabilitasiesentra asook in die gemeenskap. Grondig onderlê in die toepaslike mediese, biologiese en sosiale wetenskappe, asook in die terapeutiese vaardighede van die psigiatriese verpleegkunde, moet die verpleegkundige gemoeid met die geestesvertraagde persoon egter ook leer om die konsep "normalisering" in haar benadering tot die persoon te bring - dit is, in die beraming van sy behoeftes, in die beplanning van sy versorging en rehabilitasie, in die uitvoering van hierdie beplanning en in alle fasette van evaluering.

$\mathbf{P}$ reparation for a specific responsibility requires an answer to the following question: Who is being prepared to do what with whom and in what location? The answer to this question will serve as a basis for setting forth certain guidelines for the educational preparation for nurses to render a service to the mentally retarded $(1, \mathrm{p} .19)$.

The answer to who is being prepared, as far as this paper is concerned, is the nurse, because the health services have the responsibility for all mentally retarded children from birth to six years, and after the age of six years for all those persons who are not suitable for special education or training. The answer to the second part of the question is summarised in the imposed task, namely to render a service to the mentally retarded. The location in which this service must be rendered is vast and extends from the community to the Care and Rehabilitation Centres. It includes the preventive, promotive, curative and rehabilitative dimensions of mental retardation.

In the Republic of South Africa it is primarily the registered and/or enrolled psychiatric nurse who is being prepared to care for the mentally retarded.

The professional registered psychiatric nurses are trained at different levels of educational preparation. At the basic level of nursing education three courses are offered:
- A three years and six months diploma course leading to registration as a general nurse and psychiatric nurse.

- A three years diploma course for registration as a psychiatric nurse.

- The third type of registered nurses are graduates of different degree programmes in nursing offered at university level.

At the post-basic level after registration as a general nurse there is a one year course for registration as a psychiatric nurse.

In all the above-mentioned courses mental retardation nursing care forms an integral part of the psychiatric nursing curriculum.

According to the South African Nursing Council directive the formal education in mental retardation should include the following: genetic and congenital causes; classification and clinical varieties; prevention; psychological assessment; education, training and all other rehabilitative methods; socialisation; community care of the mentally retarded; legal aspects $(8,1)$.

The minimum required periods of instruction for the complete course in psychiatric nursing, which includes the section on mental retardation, are two hundred and forty periods. Surely with such a comprehensive field 
such as psychiatric nursing the curriculum section on mental retardation couldn't possibly receive at the most more than one third of the allocated teaching periods. That amounts to approximately eighty teaching periods. In the post-basic diploma course for registration as a psychiatric nurse the prescribed minimum required periods of instruction are even less, namely only one hundred and twenty periods for Psychiatric Nursing Science and Art III of which mental retardation is a component.

In both the three years and three and a half years as well as in the one year basic courses the prescribed period of clinical instruction and practica amounts to four weeks only. The clinical instruction and practica period for degree students is a mere two weeks.

Enrolled nurses are the second major category of nurses who are being prepared to render a service to the mentally retarded. Their training consists of a two year course for the certificate for enrolment as an enrolled nurse. As part of their course they specialise in one of five elective courses viz. care of the aged, nursing care of mentally defective persons and community health nursing, general nursing, psychiatric nursing.

The prescribed curriculum of the S A Nursing Council for the elective course in the nursing care of mentally defective persons represents a detailed and comprehensive syllabus on the subject-matter as well as sufficient time for the necessary clinical experience.

The field of mental retardation nursing includes the following in this course:

Awareness of basic and individual needs, psychological manifestations of retarded development, intellectual, social and emotional needs and problems, anatomical and physiological manifestations and associated handicaps of mental retardation, special therapeutic skills as well as lectures on nutrition and dietetics, first aid, psychotropic medicines, facilities for the mentally handicapped and administrative aspects $(8,2)$.

The most recent educational development in preparing the nurse to render a service to the mentally retarded is a post-basic course for registered psychiatric nurses called the Advanced Diploma in Psychiatric Nursing Science. This course also makes provision for electives in which prospective students may specialise, namely: advanced nursing in child psychiatry, advanced nursing in community psychiatry, and advanced nursing of the mentally retarded.

The above-mentioned courses constitute the basis of a training programme for registered and enrolled nurses who are expected to render a service to the mentally retarded. Does this training equip the psychiatric nurse adequately to care for the mentally retarded?

The Briggs Committee (7) in 1972, rejected 'nurse' training as appropriate to the major needs of the mentally retarded. They recommended the emergence, in the long term, of a new caring profession for mental han- dicap, with mental sub-normality trained nurses as its nucleus.

In the author's opinion the latter two courses were introduced by the S A Nursing Council with the contemplated objective to envisage such a new caring profession of mental retardation nurses with registered psychiatric and enrolled nurses as its nucleus.

In dealing with the second part of the postulated question one has to have a closer look at who the mentally retarded are, their needs, and how they must be cared for.

The mentally retarded who primarily would be the responsibility of the nursing profession are the severely mentally retarded, the mentally retarded children of pre-school age, and secondary all the other categories of mentally retarded in Care and Rehabilitation Centres who need institutionalised care.

A fundamental concept in rendering a service to the mentally retarded that needs emphasis is that the mentally retarded are not sick but are handicapped or impaired in their ability to live independently and to meet the critical demands of society, and that the nursing profession, in their caring function, have an obligation to help them live as normal a life as possible.

The major aims of a service to the mentally retarded are to achieve rehabilitation into the community or maximum personal and social independence within a residential setting.

Thus, the nurse has to be prepared to provide for the normal human as well as the exceptional needs of the mentally retarded. The primary needs of the mentally retarded person are 'home' care, education, occupational and social training. This concept is consistent with the term encompassed by the 'normalisation' principle in the Swedish philosophy of care $(5, \mathrm{p} .970)$.

Wolfensberger defined the goal of normalisation as the development of behaviours and characteristics by the mentally retarded person that are average or normal for the individual's culture. The techniques and environments used to attain the goal were also to be the usual or accepted methods for the general culture (1, p.33).

Nurses should be taught to review their practice and use of the nursing process; they have to incorporate the concept of normalisation into their assessment of the person's needs, planning of care and rehabilitation, implementation of the care and rehabilitation plan and into all facets of evaluation.

Apart from the primary needs, research has shown that there are some other exceptional needs of the mentally retarded.

A survey in 1972 showed that many of the children and adults in institutions for the mentally retarded were very dependent, and require considerable basic care from the nursing personnel: $20 \%$ of those surveyed were severely incontinent, while $23 \%$ were reported to need 
much assistance to feed, wash and dress (5, p.970).

These figures confirm that basic care in a care and rehabilitation centre is needed for a significant proportion of the severely and profoundly mentally retarded. But even for these persons skilled and well prepared nurses are required because it has been proven that with the provision of structured learning experiences and 'normal' social environment most of these persons can acquire basic self-help and can learn to modify difficult and disturbed behaviours.

Kushlick has reported that "no child has been found to fit the description of 'helpless idiot', 'vegetable', 'non-responsive' in spite of the fact that only a minority have speech or can even score on an IQ-test. All are in need of or are capable of responding to individual training programmes on operant conditioning lines"' (5, p.970).

The care skills and knowledge required by nurses of the mentally retarded to meet these sort of needs are not just those that are general to nursing. They are also those of a parent, a skilled residential social worker with a wide knowledge of how individual relationships can be developed and maintained and an understanding of group inter-action, and of specialist educator able to provide carefully structured teaching programmes ( 5 , p.970).

McCoull, in a large survey of 6258 retarded people living in hospitals and in the community, found that $6,4 \%$ were at the time of examination suffering from a chronic illness of one sort or another. Most of the illnesses reported were ones which did not require skilled nursing care $(5, \mathrm{p} .969)$.

To provide for the medical nursing needs of the mentally retarded it is essential that the nurse should be skilled at recognising the first signs of illness, particularly in those too retarded to communicate. They should also be equipped to deal with emergencies such as status epilepticus.

Furthermore they should have extensive knowledge about heart and respiratory disorders and the preventative measures necessary to reduce the spread of communicable diseases within a residential situation. Nutrition, dietetics and psychopharmacology should also be included in the curriculum.

The needs of the mentally retarded with reference to psychiatric illness have been studied by researchers. Careful examination of the studies by Leck, Gordon and McKeown, Williams and McCoull, suggest that $10 \%, 11 \%$ and $12 \%$ respectively, of the patients surveyed, showed significant psychiatric disorder (5, p.969).

Therefore a minority of mentally retarded do need skilled psychiatric nursing care.

In preparation for mentally retarded nursing the professional training of the nurse should be matched to the following roles, functions and responsibilities:
Determination of the needs of the mentally retarded; description and assessment of handicaps; examination and utilisation of the services that will maximise personal independence and social adjustment; as well as organisation and co-ordination of specialist services for those with special or exceptional needs $(5$, p.970).

What guidelines could be proposed for the educational preparation for nurses?

As previously mentioned, the Briggs Report in its section on New Career Developments in mental handicap, recommended the emergence of a new caring profession for mental handicap, with mental sub-normality trained nurses as its nucleus.

Another more recent report, the Jay Committee (1979), proposed the training of two basic grades of residential care staff for the mentally retarded, i.e.:

- qualified care workers with a certificate in general residential care and mental handicap aspects, either children or adults;

- in-service trained care workers.

This group consists of the nursing and care assistants who would have formal in-service training of at least two weeks each year.

Because it sees the mentally retarded as needing primary residential care rather than treatment in the clinical sense, the Committee feels the care staff should only be trained in the basics of residential care.

For qualification the Committee therefore proposes a programme of training with the accent on caring for mentally retarded people, rather than training mental retardation care staff with the accent on the residential setting.

The Committee also decided that the Central Council for Education and Training of Social Workers should take over the training of these care workers. They maintained that the current nurse training, supervised by the nursing councils, does not place enough emphasis on the social and educational role $(4$, p.393).

As far as this committee is concerned we thus see that they suggest the emergence of totally new category of care staff without any resemblance to nurse training.

Critique why the above-mentioned recommendation of the Jay Report will not succeed is abundant in recent literature and the author tends to agree with some of it. One such author is J. Bavin -

"The Committee makes the profound mistake of thinking that residential care is the fundamental problem. Rather it is the objective, and the problem is disordered behaviour.

I can demonstrate to anyone, at any time, numbers of mentally handicapped people who have been in splendid residential care at home and in local authority hostels, and yet have been unable to benefit from these opportunities to sample the good community life. They have been transferred to sub-normality hospitals because people could not cope with the problems of disordered 
behaviour, multiple handicaps and the burden of physical care.

If on the other hand, I were to draw up a list of the personal characteristics, knowledge, skills and techniques required to deal effectively with the problems of behaviour presented in profusion by many mentally handicapped people in hospital, it would leave few people with any doubts as to where the main training is needed.

To give just a short list we expect staff in hospitals to be expert in behaviour modification, Makaton, the recognition of mental illness, epilepsy, drug actions and side-effects. Behaviour modification itself is a technical subject of some complexity, and requires considerable training, to say nothing of self-control and selfwareness $(2, \mathrm{p} .822)$.

If residential care is the main skill area required to look after mentally retarded people in a humane way and a normal domestic environment, why can't many parents manage it? . . . Certain of mentally retarded persons have a temporary or permanent need for specialized skills, others would apparently need general, paediatric and psychiatric treatment which can only be carried out by appropriate trained nursing staff" (2, p. 823).

There will always be a need for a skilled, committed, professional nursing work force to treat, train and care for, especially that group of mentally retarded persons who will be rejected from the educational and social facilities provided by care workers from other State Departments.

A further point in rejecting the recommendations of the Jay Report is that the major problem with registered psychiatric nursing training has not been the syllabus, which is periodically updated, but the inadequate periods of practical experience in obsolete facilities.

The last aspect of the postulated question still needs answering namely 'in what location?'

The function of the nurse in mental retardation has three dimensions - primary, secondary and tertiary. The domain of her practice includes the community and the institution, the nurse works with the mentally retarded person in his family circle, his occupational environment, and in Care and Rehabilitation centres. She is employed by many different employers, each of them rendering a service of some kind to the mentally retarded. The practising professional nurse who works at maternity hospitals, ante- and post-natal clinics, at school clinics, child guidance clinics, etc. also plays a role in rendering a service to the mentally retarded. Mental retardation nursing education has to encompass the preventative, promotive, curative and rehabilitative aspects of care.
With reference to the above discussion the following guidelines are proposed for the educational preparation for nurses to render a service to the mentally retarded.

The curriculum should make provision for the following learning experiences as well as ample provision for the necessary clinical experiences.

\section{See next page for guideline.}

The curriculum should also include those biological and medical sciences that provide students with depth of theoretical knowledge to explain causation and related problems. Another area of content needed comes from the behavioural sciences, including human development, which enlarges the student's repertoire of developmental concepts and provides her with the intellectual tools for making more sophisticated assessments and comparisons between normal and deviant of human behaviour and inter-action as well as giving the nurse a theoretical foundation for designing environmental intervention directed toward behaviour control $(3, \mathrm{p} .639)$.

The major effort in the educational preparation of the nurse to render a service to the mentally retarded should be directed towards the expression of the potentialities of the human being, and towards maintaining his integrity, while at the same time conserving these resources so that he can cope with those developmental crises which originate from deviation in growth (3, p.634).

The nurse who specialises in the nursing care of the mentally retarded must be prepared to intervene with a high level of skill in a caretaking, maintaining, and sustaining manner.

\footnotetext{
REFERENCES

BOOKS

1. Curry, J. B. \& Peppe, K. K.: Mental Retardation, Nursing approaches to care. The C Mosby Company. Saint Louis, 1978

ARTICLES

2. Bavin, J.: Jay Report Critique - 1, Why the recommendations will not succeed. Nursing Times. May, 17th, 1979

. Murray, L. \& Barnard, K.E.: The Nursing Specialist in Mental Retardation. Nursing Clinics of North America. Volume I, No. 4. December, 1966.

Special Report: The Jay Recommendations. Nursing Times. March 8, 1979

5. Thomas, Derek: A New Caring Profession. Is is necessary? Nursing Times. July 26, 1973

REPORTS

6. Report of the committee of enquiry into mental handicap nursing and care. HMSO., 1979

7. Report of the committee on nursing, Cmnd 5115, HMSO., October, 1972.

8. Regulations of the South African Nursing Council.

8.I No. R 1923 August 31, 1979.

8,2 No. R 1664 August 03, 1979
} 


\begin{tabular}{|c|c|}
\hline $\begin{array}{l}\text { PRIMARY DIMENSION } \\
\text { or } \\
\text { PREVENTATIVE LEVEL }\end{array}$ & $\begin{array}{l}\text { Genetic counseling } \\
\begin{array}{ll}\text { Pre-natal Care } & \text { early and on-going assessment } \\
& - \text { recognition of maternal high risk } \\
& \text { factors } \\
- & \text { ante-natal testing and interpre- } \\
& \text { tation } \\
- & \text { appropriate interventions } \\
- & \text { patient education } \\
\text { Care of the newborn } & - \text { neurological assessment } \\
\text { Care of high-risk infants and families }\end{array} \\
\end{array}$ \\
\hline $\begin{array}{l}\text { SECONDARY DIMENSION } \\
\text { - Identification } \\
\text { - Intervention }\end{array}$ & $\begin{array}{l}\text { - Neuromotor development: assessment and implications } \\
\text { - Developmental screening } \\
\text { - Identification of the visible child in the community } \\
\text { - Maximising services for the mentally retarded - co-ordinated } \\
\text { efforts } \\
\text { - Behavioural home management programs } \\
\text { * Nursing interventions in the family approach } \\
\text { - support } \\
\text { information giving and health teaching } \\
\text { - crisis intervention } \\
\text { - Counselling } \\
\text { - Communication and collaboration with community agencies and } \\
\text { other professionals } \\
\text { - Institutionalised nursing care } \\
\text { - Evaluation } \\
\text { - Nursing care plans - Nursing Process } \\
\text { - Social reorientation } \\
\text { continence and personal hygiene } \\
\text { dressing } \\
\text { mobility } \\
\text { self-help in feeding } \\
\text { speech } \\
\text { appreciation of number and money } \\
\text { socialising with others } \\
\text { work } \\
\text { social activities } \\
\text { hobbies and sport activities }\end{array}$ \\
\hline $\begin{array}{l}\text { TERTIARY DIMENSION } \\
\text { or } \\
\text { REHABILITATIVE } \\
\text { LEVEL }\end{array}$ & - The transition from institution to community living \\
\hline
\end{tabular}

(1, pp.89-199). 